\title{
Index-Based Measurement of Creative Industries' Impact on National Economy
}

\author{
Ugne Daubaraite-Radikiene, Grazina Startiene
}

\author{
Kaunas University of Technology \\ K. Donelaicio st. 73, LT-44029, Kaunas, Lithuania \\ E-mail.ugne.daubaraite@gmail.com; grazina.startiene@ktu.lt

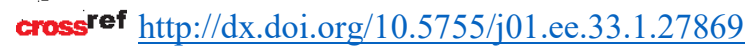

\begin{abstract}
For more than 20 years creative industries (CI) have been experiencing increasing attention from both academia and policymakers alike. Capable of creating jobs, invigorating cities and regions, cultural and social life, contributing to the increase in value added, exports and quality of life, numerous studies proved CI to have broad impact on national economy, as evident not only in economic, but also in sociocultural and environmental areas. Authors aim to develop a model of CI impact on national economy integrating economic, sociocultural, and environmental indicators, to create the index for measuring the CI impact on national economy, and to adapt it empirically to the case of the EU countries in 2008 - 2016. Research confirms that the impact of CI is observed in economic, sociocultural, and environmental impact areas. CIIE index allows estimating CI impact on national economy and enables to draw comparisons among the EU countries in 2008 - 2016 based on CI impact on national economy. This study reveals direct dependence between the factors of CI development and CI impact on national economy. With reference to the index describing the conditions of CI development (Global Creativity Index), three clusters of the EU countries were identified using CI impact on national economy (CIIE) index. Clustering confirms that historical, social, economic, and political development of a country determines conditions for CI emergence and development, and, consequently, influences CI impact on national economy.
\end{abstract}

Keywords: Creative Industries; Cultural Industries; Creative Economy; Creativity Index; European Union.

\section{Introduction}

Since most Western countries lean towards ideas and knowledge generation as opposed to producing services and goods, the field of creative industries (CI) gathers increasing attention from academia and policy makers alike. In addition to this, arguments backing CI as an indispensable component of modern post-industrial knowledge society grow in both number and depth: capable of creating jobs, invigorating cities and regions, cultural and social life, contributing to the increase in value added, exports and quality of life, numerous studies proved CI to have an impact on national economy. CI exceed other sectors in terms of higher than average development and new jobs (Blair et al., 2001; Florida \& Tinagli, 2004; Garnham, 2005; KEA, 2006; UNESCO, 2006; van der Pol 2007; Hotho \& Champion, 2011; Bandarin et al., 2011; De Propris 2013; Goede \& Louisa, 2012; EY, 2014; OE, 2014; Daubaraite \& Startiene, 2015; Cong 2019; Yum 2020); in addition to this, CI provide means to express cultural identity crucial for diversity (Smallbone, Bertotti \& Ekanem, 2005; Matheson, 2006; van der Pol, 2007; EC, 2010; Sigurdardottir \& Young, 2011; Bandarin et al., 2011; Barauskaite \& Verikiene, 2011; European Parliament and EU Council, 2013). Cultural diversity defines societal viability and economic success much more than cultural homogeneity (Florida, 2002; Florida and Tinagli, 2004; Florida, 2008, and other works by Florida; UNESCO, 2006; Boschma \& Fritsch, 2007; Goede \& Louisa, 2012; Daubaraite \& Startiene, 2017; Innocenti \& Lazzeretti, 2019; Yum, 2020 and other authors). It is important to note that the same holds true in countries with economies in transition (Bilan, 2019). The term 'creative industries' itself may be analysed solely in the context of information society (Flew, 2002; Thomassen, 2007; Collins et al., 2018; Yum, 2020), especially considering the latest developments in light of a global pandemic and consequential lockdowns, when all possible products and services were only available online. In addition to this, culture was always associated with the life of a city, however, a growing body of research analyses the role CI play in regional development (Collins et al., 2018; Innocenti \& Lazzeretti, 2019; Yum, 2020 and others). At the same time, since the digital revolution improved accessibility of many sectors, culture should follow the same trend (Fanea-Ivanovici \& Pana, 2020). CI undoubtedly constitute a part of digital economy and the bond between those concepts will increase and deepen in the future. Furthermore, CI should be associated with innovations, information and communication technologies (Garnham, 2005; Power \& Nielsen, 2010; Cong, 2019; Yum, 2020); therefore, it is logical that CI are the source of both economic and social development and growth, yet certain conditions are required to ensure CI emergence and further growth and development.

Scientific literature analysis proved that measuring the impact CI have on national economy is an important issue, however, it has received relatively little attention from researchers since most of the research in this field is based on measuring specific solitary indicators. In addition to this, the impact of CI on national economy is of a much broader scope, as evident not only in economic, but also in sociocultural and environmental areas. Consequently, the aim of this study is to develop an index of CI impact on national economy, integrating economic, sociocultural, and environmental indicators, and to adapt it empirically to the case of the EU countries. 


\section{Literature Review}

Undoubtedly, one of the most significant researchers of CI is Richard Florida. One of his first studies on CI and creative class is The Rise of the Creative Class (2002). At the time of its release, the book was revolutionary and drew society's and politicians' attention to the importance of CI. Later, the ideas it proclaimed were criticised, corrected, and improved, which led to a variety of approaches and viewpoints. Nevertheless, Richard Florida remains an authority in the research field of CI, creative class, and other related topics. Based on Florida's ideas, different authors developed complementing theories, proposed evaluation methodologies, debated, resulting in varied perception and evaluation of CI. Florida suggested assessing CI by the Creativity Index (2002), allowing to measure and compare creativity in different countries based on the assumption that creativity defines country's economic development. Structure of the index is presented in Table 1.

Table 1

Creativity Index (Florida, 2002)

\begin{tabular}{|l|l|}
\hline \multicolumn{1}{|c|}{ Subindex } & \multicolumn{1}{c|}{ Indicators } \\
\hline Technology & $\begin{array}{l}\text { Estimates (1) innovation as the number of patents granted per capita, and (2) high-technologies in terms of } \\
\text { size and concentration of clusters of technology-related industries (such as software, technologies, } \\
\text { biomedical products, and engineering services). }\end{array}$ \\
\hline Talent & $\begin{array}{l}\text { Estimates (1) a share of creative class in total working population, and (2) education, i.e. the number of } \\
\text { people with a bachelor's or higher degree. }\end{array}$ \\
\hline Tolerance & $\begin{array}{l}\text { Estimates (1) Gay Index, i.e. the number of homosexual couples, (2) Bohemian Index, i.e. the number of } \\
\text { artistically creative people, (3) Melting Pot Index, i.e. the relative percentage of foreign-born people. }\end{array}$ \\
\hline
\end{tabular}

Creativity Index combines technology, talent, and tolerance indices. Value of each subindex is calculated in accordance with country ranking among other countries taken into evaluation: each country is evaluated in points, and the country reaching the highest value is awarded the highest score. Creativity Index is calculated by adding evaluation points in each subindex and dividing the sum by the number of subindices.
Supplementary studies, available statistics, and the process of data gathering resulted in a corrected version of the Creativity Index: a group of researchers led by Richard Florida improved the Index so that it could be applicable worldwide. Although they modified the structure of the Index, the logic behind the calculation remained the same as that of the original Creativity Index. The Index was corrected in 2011, and it was renamed to Global Creativity Index in 2015. The latest structure of the Global Creativity Index is presented in Table 2 .

Table 2

Global Creativity Index (Florida et al., 2015)

\begin{tabular}{|l|l|}
\hline \multicolumn{1}{|c|}{ Subindex } & \multicolumn{1}{c|}{ Indicators } \\
\hline Technology & $\begin{array}{l}\text { Estimated in terms of (1) investment into R\&D as a percentage of GDP, and (2) innovations as the number } \\
\text { of patent applications per million people. }\end{array}$ \\
\hline Talent & $\begin{array}{l}\text { Estimated in terms of (1) a percentage of creative class, i.e. people working in CI out of total working } \\
\text { population, (2) access to education, i.e. a share of people studying at graduate school level out of all people } \\
\text { who graduated from high school or educational institution of similar level. }\end{array}$ \\
\hline Tolerance & $\begin{array}{l}\text { Estimated in terms of (1) tolerance towards ethnic and racial minorities, and (2) tolerance towards sexual } \\
\text { minorities. }\end{array}$ \\
\hline
\end{tabular}

Following the Creativity Index proposed by Florida (2002), Euro-Creativity Index, which is very similar to the Creativity Index, was developed (Florida \& Tinagli 2004) and adapted to measuring and comparing creativity amongst
European countries. The core idea remained the same, i.e., a country's capability to attract and retain creative people determines its economic development. The structure of the index is presented in Table 3 .

Table 3

Euro-Creativity Index (Florida \& Tinagli, 2004)

\begin{tabular}{|l|l|}
\hline \multicolumn{1}{|c|}{ Subindex } & \multicolumn{1}{c|}{ Indicators } \\
\hline Euro-Talent & $\begin{array}{l}\text { Estimated in terms of (1) a share of creative class amongst total working population, (2) the percentage of } \\
\text { population aged 24-64 with bachelor's degree or higher, and (3) the number of research scientists and } \\
\text { engineers per 1,000 workers. }\end{array}$ \\
\hline Euro-Technology & $\begin{array}{l}\text { Estimated in terms of (1) the number of patents per million people, (2) the number of high-tech patents per } \\
\text { million people, and (3) R\&D expenditure as percentage of GDP. }\end{array}$ \\
\hline Euro-Tolerance & $\begin{array}{l}\text { Estimated in terms of (1) attitudes towards minorities (based on the Eurobarometer Survey), (2) values and } \\
\text { attitudes that cover different aspects of the value system (such as religion, nationalism, family, women's } \\
\text { rights, divorce, and abortion), and (3) attitudes towards self-expression, quality of life, democracy, and } \\
\text { culture. }\end{array}$ \\
\hline
\end{tabular}

The Euro-Creativity Index follows the same calculation logic as the Creativity Index: the value of Euro-Creativity Index is the sum of country's scores of all three subindices divided by the maximum possible score.
Based on the works of Florida (2002), and Florida and Tinagli (2004), Hui et al. (2006) developed an index to measure creativity in Hong Kong. The Hong Kong Creativity Index was meant to measure the impact of creativity, and to 
evaluate the influence of creativity on economy of the region. The index structure is presented in Table 4.

Hong Kong Creativity Index was calculated for each year of research (from 1999 to 2004), considering that 100 per cent value was reached in each area in 2004. Therefore, to apply this index in further estimations, a reference point should be chosen, and index values should be recalculated accordingly.

Table 4

Hong Kong Creativity Index (Hui et al., 2006)

\begin{tabular}{|l|l|}
\hline \multicolumn{1}{|c|}{ Subindex } & \multicolumn{1}{c|}{ Indicators } \\
\hline $\begin{array}{l}\text { Structural - } \\
\text { institutional capital }\end{array}$ & $\begin{array}{l}\text { Estimated in terms of (1) independence of legal system, (2) perception of corruption, (3) freedom of } \\
\text { expression, (4) ICT infrastructure, (5) strength of social and cultural system, (6) accessibility to community } \\
\text { facilities, (7) financial infrastructure, and (8) entrepreneurship conditions. }\end{array}$ \\
\hline Human capital & $\begin{array}{l}\text { Estimated in terms of (1) government investment in R\&D and education, (2) share of knowledge economy } \\
\text { jobs, and (3) labour force mobility. }\end{array}$ \\
\hline Social capital & $\begin{array}{l}\text { Estimated in terms of (1) development of social capital, e.g. the amount of charity donations, (2) attitudes } \\
\text { towards traditional norms and values prevailing in the society, and (3) involvement in social decision- } \\
\text { making, elections. }\end{array}$ \\
\hline Cultural capital & $\begin{array}{l}\text { Estimated in terms of (1) government investment into culture sector, (2) societal attitudes towards cultural } \\
\text { events and environmental protection, and (3) participation in cultural activities. }\end{array}$ \\
\hline
\end{tabular}

Analysis of the most widely used CI and related fields measurement indices reveals that such evaluation is a relevant and perspective approach, especially when estimating the impact of $\mathrm{CI}$ on economy under the conditions of growing integration and globalisation.

\section{Methodology of the Study}

This study suggests an index-based CI impact on national economy measurement by identifying core CI development determinants (Florida, 2008; Comunian et al.,
2010; Tomczak \& Stachowiak, 2015; White et al., 2014, etc.) and CI impact on national economy areas (UNESCO, UNDP, UNCTAD, EC, OE, EY, KEA reports; Florida \& Tinagli, 2004; Potts \& Cunningham, 2008; White et al., 2014; Levickaite \& Reimeris, 2011; Oakley, 2004; Champion, 2010; De Propris, 2013; Matheson, 2006, etc.) while combining the constituents into a conceptual framework of CI impact on national economy (see Figure 1).

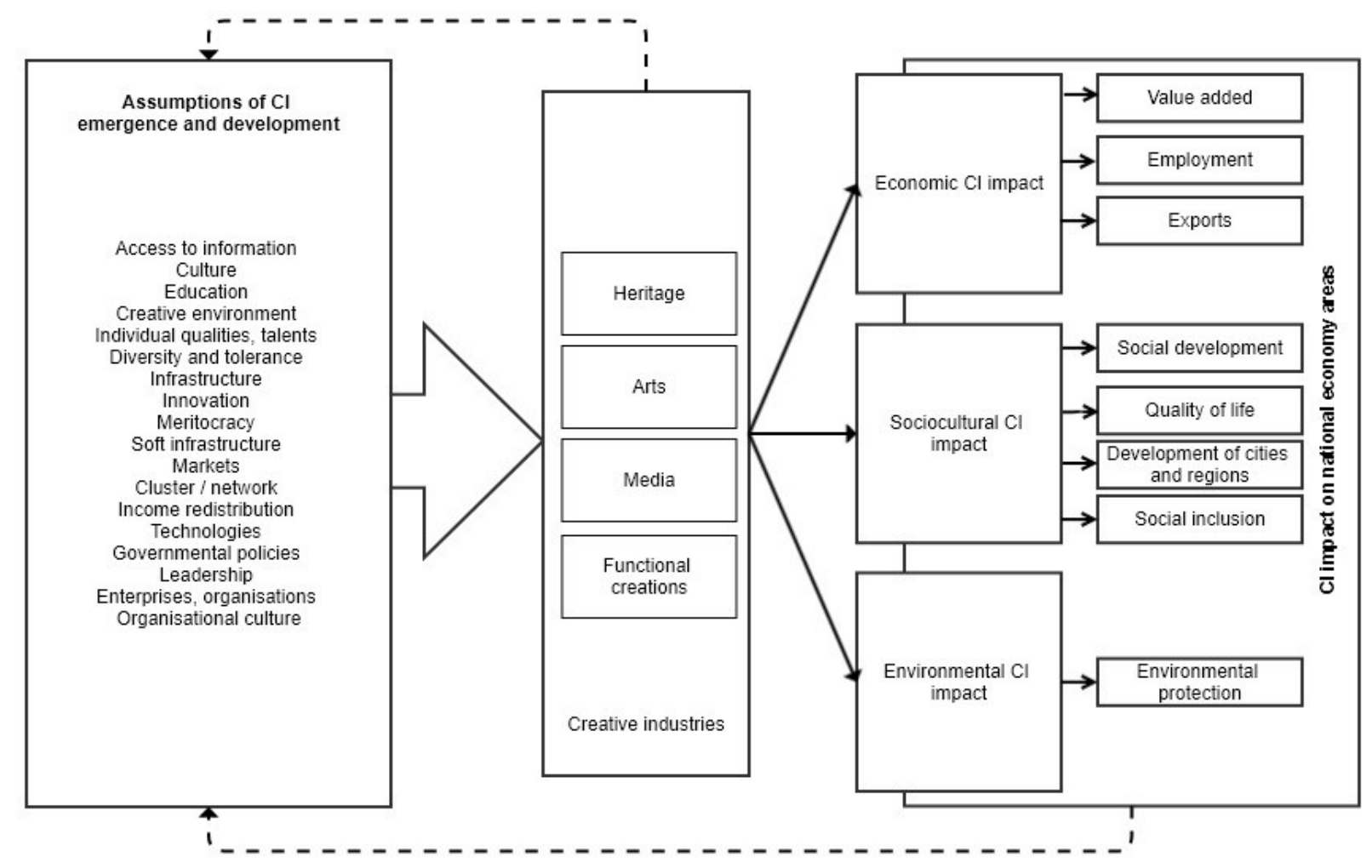

Figure 1. Conceptual Framework of the Impact of Creative Industries on National Economy (Developed by Authors)

It is crucial to note that CI impact on national economy varies from area to area. Scientific literature analysis revealed that $\mathrm{CI}$ impact on national economy manifests itself via economic impact (Florida \& Tinagli, 2004; Cunningham \& Potts, 2014; Pitts, 2015; Daubaraite \& Startiene, 2017; Collins et al., 2018; Cong, 2019; Yum,
2020, etc.), sociocultural impact (Oakley, 2004; van der Pol, 2007; Pratt, 2008; White, 2010; Levickaite \& Reimeris, 2011; Sigurdardottir \& Young 2011; Daubaraite \& Startiene 2015; Yum 2020, etc.), and environmental impact (Bandarin, Hosagrahar, \& Albernaz, 2011; Goede \& Louisa, 2012; Collins et al., 2018; Bilan et al., 2019, etc.). 
Based on the conceptual framework, CI impact on national economy (CIIE) index and its components are defined by the following equations:

$$
\mathrm{CIIE}=w_{1} E C_{\mathrm{CIIE}}+w_{2} S C_{\mathrm{CIIE}}+w_{3} E N_{\mathrm{CIIE}}
$$

where $E C_{\text {CIIE }}$ is the subindex of CI economic impact, $S C_{\text {CIIE }}$ is the subindex of CI sociocultural impact,

$E N_{\text {CIIE }}$ is the subindex of CI environmental impact, and $w_{1} \ldots w_{3}$ are weights of CI impact on national economy subindices, the sum of which equals 1 ;

$E C_{\mathrm{CIIE}}=\mathrm{a}_{1} J_{\mathrm{E}}+a_{2} V A_{\mathrm{E}}+\mathrm{a}_{3} E_{\mathrm{E}}$,

where $E_{\text {CIIE }}$ is the subindex of CI economic impact, $J_{\mathrm{E}}$ is the number of jobs created by CI,

$V A_{\mathrm{E}}$ is the value added created by $\mathrm{CI}$,

$E_{\mathrm{E}}$ is the exports created by CI,

$a_{1} \ldots a_{3}$ are weights of $\mathrm{CI}$ economic impact subindices, the sum of which equals 1 ;

$S C_{\mathrm{CIIE}}=b_{1} S D_{\mathrm{SC}}+\mathrm{b}_{2} Q L_{\mathrm{SC}}+\mathrm{b}_{3} R U_{\mathrm{SC}}+\mathrm{b}_{4} S I_{\mathrm{SC}}$,

where $S C_{\text {CIIE }}$ is the subindex of CI sociocultural impact, $S D_{\text {SC }}$ is the social development caused by CI,

$Q L_{\mathrm{SC}}$ is the quality of life caused by CI,

$R U_{\mathrm{SC}}$ is the regional and urban development caused by $\mathrm{CI}$,

$S I_{\mathrm{SC}}$ is the social inclusion caused by $\mathrm{CI}$, and $b_{1} \ldots b_{4}$ are weights of CI sociocultural impact subindices, the sum of which equals 1 ;

$E N_{\mathrm{CIIE}}=E N_{\mathrm{E}}$,

where $E N_{\mathrm{CIIE}}$ is the subindex of environmental impact of CI, $E N_{\mathrm{E}}$ is the environmental impact caused by CI.

Index of $\mathrm{CI}$ impact on national economy may acquire values from 0 (CI have no influence on country's economy) to 1 (country's economy is solely based on $\mathrm{CI}$ ). The change of index from 0 to 1 shows the impact of CI on national economy, i.e. the closer index values are to 1 , the more significant is the CI economic sector.

It is important to note that impact areas are not equally significant, thus attributing different weight coefficients ensures they are distinguished from one another, and the impact of CI on each is reflected properly in the index.

Each area of CI impact on economy is estimated using relevant indicators. It is fair to mention that economic impact measurement could include indicators of circular economy as well as environmental impact could contain indicators to evaluate waste management specifics, however, literature and research review shows that data on such indicators cannot be connected to CI explicitly. In addition to this, when selecting indicators, criteria of indicator reliability and data accessibility (UN 2007) were followed. The structure of CIIE index combining indicators used for evaluation is presented in Table 5.

Table 5

Structure of CIIE

\begin{tabular}{|c|c|c|c|}
\hline $\begin{array}{l}\text { Area of } \\
\text { impact }\end{array}$ & $\begin{array}{l}\text { Directions } \\
\text { constituting the } \\
\text { impact area }\end{array}$ & Direction indicators & Calculation of indicators \\
\hline \multirow{3}{*}{ Economic } & $\begin{array}{l}\text { Jobs created by } \\
\text { CI }\end{array}$ & $\begin{array}{l}\text { Percentage of people employed in } \\
\text { CI }\end{array}$ & $\begin{array}{l}\text { Number of people employed in CI / total number of } \\
\text { working people in the country x } 100 \text {. }\end{array}$ \\
\hline & $\begin{array}{l}\text { Value added } \\
\text { created by CI }\end{array}$ & $\begin{array}{l}\text { Share of value added created by CI } \\
(\%)\end{array}$ & $\begin{array}{l}\text { Value added created by CI (MEUR) / value added in the } \\
\text { country (MEUR) x } 100 .\end{array}$ \\
\hline & $\begin{array}{l}\text { Exports created } \\
\text { by CI }\end{array}$ & Share of exports created by CI (\%) & $\begin{array}{l}\text { Exports created by CI (MEUR) / exports value in the } \\
\text { country (MEUR) x } 100 .\end{array}$ \\
\hline \multirow{8}{*}{ Sociocultural } & \multirow{3}{*}{$\begin{array}{l}\text { Social } \\
\text { development } \\
\text { caused by CI }\end{array}$} & Freedom of expression & $\begin{array}{l}\text { Evaluation received from the official website of } \\
\text { Reporters Without Borders RSF.org. }\end{array}$ \\
\hline & & $\begin{array}{l}\text { Level of education of workers in } \\
\text { the CI }\end{array}$ & $\begin{array}{l}\text { Number of people with higher education in the CI / total } \\
\text { number of people employed in CI x } 100 .\end{array}$ \\
\hline & & $\begin{array}{l}\text { Difference in earnings of men and } \\
\text { women working in the CI }\end{array}$ & $\begin{array}{l}\text { Average man's hourly gross earning (EUR) - average } \\
\text { woman's hourly gross earnings (EUR) / average man's } \\
\text { hourly gross earning (EUR) x } 100 .\end{array}$ \\
\hline & $\begin{array}{l}\text { Quality of life } \\
\text { caused by CI }\end{array}$ & $\begin{array}{l}\text { Weekly load of working hours of } \\
\text { people employed in the CI }\end{array}$ & $\begin{array}{l}\text { Number of working hours per week / total number of } \\
\text { hours per week x } 100 .\end{array}$ \\
\hline & \multirow{3}{*}{$\begin{array}{l}\text { Regional and } \\
\text { urban } \\
\text { development } \\
\text { caused by CI }\end{array}$} & $\begin{array}{l}\text { Household costs for cultural } \\
\text { products according to purchasing } \\
\text { power standards }\end{array}$ & $\begin{array}{l}\text { Evaluation obtained from the official EUROSTAT } \\
\text { website. }\end{array}$ \\
\hline & & $\begin{array}{l}\text { Percentage of people who visit } \\
\text { cultural objects }\end{array}$ & $\begin{array}{l}\text { Percentage of people aged } 25-64 \text { who went to cinema, } \\
\text { theatre or concert, visited cultural objects (historical } \\
\text { monuments, museums, art galleries, objects of } \\
\text { archaeological value) at least once within the last } 12 \\
\text { months. Evaluation obtained from the official } \\
\text { EUROSTAT website. }\end{array}$ \\
\hline & & $\begin{array}{l}\text { Share of CI enterprises in total } \\
\text { number of country's enterprises }\end{array}$ & $\begin{array}{l}\text { Number of CI enterprises / total number of enterprises in } \\
\text { the country x } 100 \text {. }\end{array}$ \\
\hline & $\begin{array}{l}\text { Social inclusion } \\
\text { caused by CI }\end{array}$ & Global tolerance index & $\begin{array}{l}\text { Evaluation obtained from the report The Global } \\
\text { Creativity Index (Florida et al., 2015). }\end{array}$ \\
\hline Environmental & $\begin{array}{l}\text { CI impact on } \\
\text { environment } \\
\text { protection }\end{array}$ & $\begin{array}{l}\text { Share of air pollution generated by } \\
\mathrm{CI} \text { enterprises }(\%)\end{array}$ & $\begin{array}{l}\text { Air pollution caused by CI enterprises (PM10, t) / air } \\
\text { pollution caused by enterprises in the country }(\mathrm{PM} 10, \mathrm{t}) \\
\mathrm{x} 100 \text {. }\end{array}$ \\
\hline
\end{tabular}


The area of sociocultural CI impact on national economy is rather complex and much broader in scope, especially in comparison to the economic impact area: analysis of social development, quality of life, regional and urban development, and social inclusion directions revealed that each of the impact directions can be evaluated by different indicators; most relevant ones were selected by usage frequency in CI research and accessibility of data. Environmental quality and natural conditions are assessed in terms of sector's ability not to pollute or worsen natural environment. Analysis of indicators and indices disclosed that the impact of $\mathrm{CI}$ and related areas on environment protection is usually measured by air pollution level (Fox, 2013; OECD, 2013; Social Progress Imperative 2016; OECD 2016, etc.). Criteria, such as water pollution and environmental noise, are not as frequent in measuring the environmental impact (OECD 2013), thus the measure of air pollution caused by $\mathrm{CI}$ is used to estimate the value of environmental impact subindex. Since the environmental impact of CI is defined by one indicator, the indicator's weight $E N_{\mathrm{E}}$ equals 1.

Having calculated values for each subindex using formulas (2), (3), and (4), we normalise the data following the rules of Global Creativity Index calculation, i.e. obtained subindex values are divided by the number of countries studied.

\section{Empirical Study}

This study is based on statistical data of European Union (EU-28) countries (based on the data provided by EUROSTAT, Reporters without Borders, The Global Creativity Index (Florida et al., 2015)) that define the impact of CI on national economy. It should be noted that the majority CI studies confirmed needed statistical data to not be detailed, accurate, or present in general (e.g. Florida \& Tinagli, 2004; Pratt, 2008; Goede \& Louisa, 2012; White et al., 2014; De Beukelaer, 2014; Pitts, 2015; Daubaraite \& Startiene, 2017; Bilan et al., 2019, etc.). On one hand, this issue is caused by different CI definitions; on the other hand, countries collect different statistical data. This research uses uniform CI definition established by UNCTAD (2008), dividing CI into four subsectors: heritage, arts, media and functional creations. CI subsectors were identified using NACE rev. 2 classification; and in order to ensure adequacy and comparability of the data used in the study, creative sectors in all EU countries are described according to the classification provided by EUROSTAT, the statistical office of the EU. It is crucial to note that while the first term to be used was "cultural industries", due to changes in political and socioeconomic circumstances, cultural industries are now a part of CI. This perspective is sustained in this research, as cultural industries fall under CI due to NACE rev. 2 classification. CI subsectors according to the NACE rev. 2 classification system are given in Table 6.

Table 6

Classification of CI Categories According to NACE rev. 2

\begin{tabular}{|l|l|}
\hline \multicolumn{1}{|c|}{ CI categories } & \multicolumn{1}{c|}{ Type of economic activity according to NACE rev. 2 classification system } \\
\hline Cultural heritage & Class $\mathrm{R}$ - Arts, entertainment and recreation \\
\hline \multirow{2}{*}{ Arts } & $\begin{array}{l}\text { Class } \mathrm{R} \text { - Arts, entertainment and recreation } \\
\text { Class } \mathrm{M} \text { - Professional, scientific and technical activities }\end{array}$ \\
\hline Media & Class $\mathrm{J}$ - Information and communication \\
\hline Applied creativity & Class $\mathrm{M}$ - Professional, scientific and technical activities \\
\hline
\end{tabular}

Although classes J, M and R of NACE rev. 2 include activities that are not attributed to CI per se, this is the prerequisite for data collection in the analysis and comparison of all EU-28 countries. It should be noted that when the same classes are chosen, deviations in all countries are analogous; therefore, the selected assessment benchmark allows for comparative analysis.

In order to evaluate CI impact on national economy, weights of CIIE subindices are determined, and then the analysis and assessment of each subindex is provided. CIIE values serve as a basis for assessing EU countries in accordance to the impact $\mathrm{CI}$ have on national economy.

Subindex weights were determined by expert survey: CI experts provided their competent and practice-based insights (see Table 7 for reliability of expert survey). In order to ensure equal representation of all CI subsectors, two experts from each subsector took part in the survey. Three experts have more than 10 years' experience in CI, three experts have 5-10 years and two have less than 5 years' experience. Kendall's coefficient of concordance shows that there is quite little agreement among experts. However, as the p-value of Friedman test is less than the significance level of 0.05 , the null hypothesis (H0: there is no significant difference in rating of questions) is rejected and we can conclude that questions are rated differently, thus survey results can be used for further research.

Table 7

Assessment of Expert Opinion Compatibility and Statistically Significant Difference

\begin{tabular}{|l|c|c|c|}
\hline \multicolumn{1}{|c|}{ Part of survey } & $\begin{array}{c}\text { Cronbach's alpha } \\
\text { coefficient }\end{array}$ & $\begin{array}{c}\text { Kendall's } \\
\text { concordance } \\
\text { coefficient (W) }\end{array}$ & $\begin{array}{c}\text { Friedman's } \\
\text { criterion } \\
\text { (p-value) }\end{array}$ \\
\hline Questions in parts B and C & 0.76 & $\mathrm{x}$ & $\mathrm{x}$ \\
\hline $\begin{array}{l}\text { Part B. Assessing the importance of indicators for CI } \\
\text { development }\end{array}$ & $\mathrm{x}$ & $\mathrm{W}=0.321$ & $\mathrm{p}=0.000$ \\
\hline $\begin{array}{l}\text { Part C. Assessing the directions of CI impact on national } \\
\text { economy }\end{array}$ & $\mathrm{x}$ & $\mathrm{W}=0.364$ & $\mathrm{p}=0.000$ \\
\hline
\end{tabular}


Based on average scores attributed to areas and directions of CI impact on national economy by experts (where 1 is least important and 5 is most important), weights of each subindex and assessment direction were determined (see Table 8).

Table 8

Weights of CIIE Subindices and Assessment Directions

\begin{tabular}{|c|c|}
\hline Subindex, assessment direction & Weight \\
\hline Subindex of economic impact EC CIIE & $\mathrm{w}_{1}=0.362$ \\
\hline Jobs created by creative industries $\mathrm{J}_{\mathrm{E}}$ & $a_{1}=0.337$ \\
\hline Value added created by creative industries $\mathrm{VAE}$ & $\mathrm{a}_{2}=0.368$ \\
\hline Exports created by creative industries $\mathrm{E}_{\mathrm{E}}$ & $\mathrm{a}_{3}=0.295$ \\
\hline Total weight of all assessment directions: & $a_{1}+a_{2}+a_{3}=1$ \\
\hline Subindex of sociocultural impact SC CIE & $\mathrm{w}_{2}=\mathbf{0 . 3 8 3}$ \\
\hline Social development $S D_{\mathrm{SC}}$ & $\mathrm{b}_{1}=0.314$ \\
\hline Improvement of quality of life QL sC & $\mathrm{b}_{2}=0.280$ \\
\hline Regional and urban development $R U_{\mathrm{SC}}$ & $\mathrm{b}_{3}=0.220$ \\
\hline Social inclusion $S I_{\mathrm{SC}}$ & $\mathrm{b}_{4}=0.186$ \\
\hline Total weight of all assessment directions: & $\mathrm{b}_{1}+\mathrm{b}_{2}+\mathrm{b}_{3}+\mathrm{b}_{4}=1$ \\
\hline Subindex of environmental impact EN CIIE & $\mathrm{W} 3=0.255$ \\
\hline Total weight of all subindices: & $w_{1}+w_{2}+w_{3}=1$ \\
\hline
\end{tabular}

Using the weights of subindices (Table 8), previous formula (1) for calculating CIIE index is:

$$
\mathrm{CIIE}=0.362 \times \mathrm{EC}_{\mathrm{CIIE}}+0.383 \times \mathrm{SC}_{\mathrm{CIIE}}+0.255 \times \mathrm{EN}_{\mathrm{CIIE}}
$$

As mentioned earlier, subindex of CI sociocultural impact is rather complex, and due this reason, several indicators are used to describe it (Table 5). Indicators for each direction are equally important, thus their weight coefficients are calculated proportionally to the number of indicators. Due to different and / or inconsistent data, CI assessment is often based on ranking (see, for example, studies by Florida, 2002; Florida \& Tinagli, 2004; Jancoras et al., 2014; Florida et al., 2015, etc.). Following the abovementioned authors, this study ranks the countries according to each assessment direction, and each of the countries is attributed a score from 1 (the lowest CI impact) to 28 (the highest CI impact) or other highest possible score considering accessibility of statistical data. In case the statistical data cannot be accessed, country gets 0 points.

Annexes 1, 2 and 3 present the calculated values of the CIIE subindex for economic, sociocultural and environmental impact, respectively, during the period 2008-2016.

CI impact on national economy is estimated using formula (5) considering economic, sociocultural, and environmental impact of CI; results are presented in Table 9 and Figure 2.

Table 9

Values of the CIIE Index 2008-2016

\begin{tabular}{|l|l|l|l|l|l|l|l|l|l|l|}
\hline & $\mathbf{2 0 0 8}$ & $\mathbf{2 0 0 9}$ & $\mathbf{2 0 1 0}$ & $\mathbf{2 0 1 1}$ & $\mathbf{2 0 1 2}$ & $\mathbf{2 0 1 3}$ & $\mathbf{2 0 1 4}$ & $\mathbf{2 0 1 5}$ & $\mathbf{2 0 1 6}$ & Average \\
\hline Austria & 0.377 & 0.374 & 0.399 & 0.408 & 0.417 & 0.394 & 0.415 & 0.422 & 0.413 & 0.402 \\
\hline Belgium & 0.497 & 0.483 & 0.493 & 0.484 & 0.486 & 0.475 & 0.473 & 0.527 & 0.530 & 0.494 \\
\hline Bulgaria & 0.371 & 0.378 & 0.371 & 0.370 & 0.337 & 0.369 & 0.369 & 0.376 & 0.362 & 0.367 \\
\hline Cyprus & 0.423 & 0.424 & 0.426 & 0.468 & 0.440 & 0.450 & 0.478 & 0.442 & 0.420 & 0.441 \\
\hline Croatia & 0.318 & 0.331 & 0.327 & 0.303 & 0.325 & 0.319 & 0.337 & 0.271 & 0.286 & 0.313 \\
\hline Czechia & 0.402 & 0.395 & 0.378 & 0.377 & 0.384 & 0.397 & 0.387 & 0.380 & 0.273 & 0.375 \\
\hline Denmark & 0.645 & 0.646 & 0.636 & 0.641 & 0.635 & 0.647 & 0.654 & 0.671 & 0.679 & 0.650 \\
\hline Estonia & 0.359 & 0.385 & 0.461 & 0.534 & 0.467 & 0.388 & 0.390 & 0.423 & 0.439 & 0.427 \\
\hline Finland & 0.557 & 0.584 & 0.588 & 0.601 & 0.594 & 0.605 & 0.621 & 0.569 & 0.592 & 0.590 \\
\hline France & 0.495 & 0.538 & 0.527 & 0.541 & 0.551 & 0.564 & 0.566 & 0.524 & 0.527 & 0.537 \\
\hline Germany & 0.418 & 0.426 & 0.471 & 0.456 & 0.470 & 0.462 & 0.477 & 0.448 & 0.434 & 0.452 \\
\hline Greece & 0.191 & 0.190 & 0.147 & 0.133 & 0.153 & 0.167 & 0.168 & 0.238 & 0.258 & 0.183 \\
\hline Hungary & 0.350 & 0.354 & 0.336 & 0.320 & 0.321 & 0.331 & 0.307 & 0.369 & 0.397 & 0.343 \\
\hline Ireland & 0.585 & 0.615 & 0.593 & 0.593 & 0.587 & 0.570 & 0.583 & 0.645 & 0.647 & 0.602 \\
\hline Italy & 0.533 & 0.547 & 0.535 & 0.529 & 0.535 & 0.543 & 0.548 & 0.506 & 0.510 & 0.532 \\
\hline Latvia & 0.390 & 0.429 & 0.439 & 0.460 & 0.451 & 0.425 & 0.432 & 0.511 & 0.514 & 0.450 \\
\hline Lithuania & 0.453 & 0.501 & 0.486 & 0.444 & 0.471 & 0.448 & 0.463 & 0.577 & 0.564 & 0.490 \\
\hline Luxembourg & 0.613 & 0.645 & 0.627 & 0.634 & 0.656 & 0.657 & 0.682 & 0.644 & 0.655 & 0.646 \\
\hline Malta & 0.403 & 0.466 & 0.453 & 0.455 & 0.465 & 0.462 & 0.466 & 0.449 & 0.466 & 0.454 \\
\hline Netherlands & 0.598 & 0.632 & 0.613 & 0.593 & 0.578 & 0.581 & 0.595 & 0.613 & 0.602 & 0.601 \\
\hline Poland & 0.210 & 0.210 & 0.241 & 0.247 & 0.246 & 0.250 & 0.266 & 0.315 & 0.281 & 0.252 \\
\hline Portugal & 0.369 & 0.368 & 0.360 & 0.336 & 0.346 & 0.358 & 0.354 & 0.355 & 0.353 & 0.355 \\
\hline Romania & 0.331 & 0.346 & 0.370 & 0.361 & 0.377 & 0.390 & 0.378 & 0.282 & 0.246 & 0.342 \\
\hline Slovakia & 0.458 & 0.467 & 0.475 & 0.478 & 0.472 & 0.460 & 0.451 & 0.432 & 0.443 & 0.460 \\
\hline
\end{tabular}




\begin{tabular}{|l|c|c|c|c|c|c|c|c|c|c|}
\hline & $\mathbf{2 0 0 8}$ & $\mathbf{2 0 0 9}$ & $\mathbf{2 0 1 0}$ & $\mathbf{2 0 1 1}$ & $\mathbf{2 0 1 2}$ & $\mathbf{2 0 1 3}$ & $\mathbf{2 0 1 4}$ & $\mathbf{2 0 1 5}$ & 2016 & Average \\
\hline Slovenia & 0.516 & 0.476 & 0.495 & 0.529 & 0.557 & 0.549 & 0.551 & 0.558 & 0.572 & 0.534 \\
\hline Spain & 0.534 & 0.468 & 0.541 & 0.518 & 0.521 & 0.510 & 0.527 & 0.426 & 0.420 & 0.496 \\
\hline Sweden & 0.522 & 0.521 & 0.537 & 0.546 & 0.542 & 0.546 & 0.558 & 0.535 & 0.527 & 0.537 \\
\hline United Kingdom & 0.627 & 0.609 & 0.620 & 0.633 & 0.643 & 0.647 & 0.656 & 0.677 & 0.684 & 0.644 \\
\hline
\end{tabular}

According to results presented in Table 9 and Figure 2, CI have the lowest impact on national economy in Greece (2008-2015) and Romania (2016), whereas the highest CI impact on national economy is observed in Denmark (20082011), Luxembourg (2012-2014), and the United Kingdom (2015-2016).

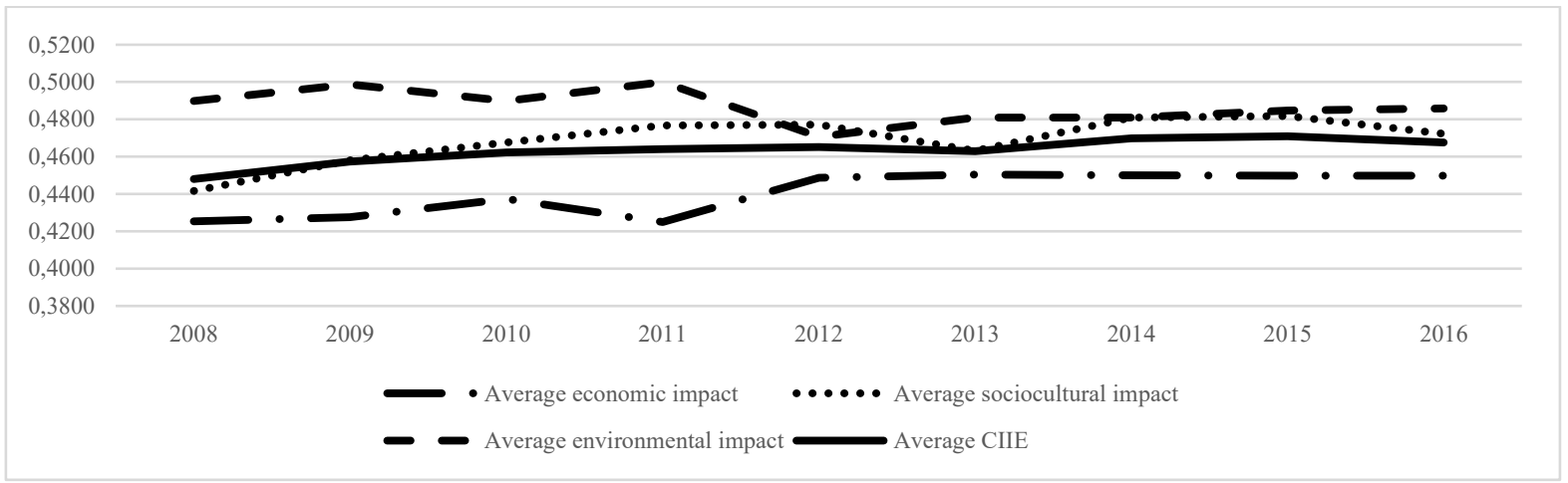

Figure 2. Dynamics of Average Economic, Sociocultural and Environmental Impact and Average CIIE 2008 - 2016

Figure 2 visually demonstrates that CI impact on national economy grew throughout the whole analysed period. It comes as no surprise that the economic impact of CI decreased following the economic crisis of 2008-2009: even though the sector was rapid to recover in 2010 , as other sectors caught up and reached pre-crisis levels, importance of CI dipped in 2011. It is important to point out that average sociocultural impact decreased in 2013 due to a drop in quality of life caused by CI: workload or number of working hours increased in CI, helping to grow its average economic impact but decreasing quality of life for the employed at the same time. Average environmental impact dropped significantly in 2012 and remained at more or less the same level throughout the analysed period, showing decreasing impact of CI on air pollution in the EU. Despite a couple of hiccups, average CIIE shows increasing importance CI have on national economy in Europe as a whole.

Theoretically, the index may vary from 0 to 1 , yet its actual lowest value is estimated in Greece in 2011 (CIIE index value is 0.133 ), and the highest value is estimated in the United Kingdom in 2016 (CIIE index value is 0.684). Calculation results are further checked for normal distribution and correlation, then used for hierarchical clustering of the analyzed EU countries.

\section{Research Results}

Analysis of scientific literature (see Figure 1) revealed a causal link between (1) the assumptions about CI emergence and development and (2) CI impact on national economy. CIIE index measures the outcome, i.e., CI impact on national economy, whereas the assumptions about CI emergence and development assess the conditions that cause CI development. In order to determine the link between the assumptions about CI emergence and development and CI impact on national economy areas, correlation analysis between Global Creativity Index of 2015 (Florida et al., 2015) and CIIE of 2016 is performed.

Table 10

P-values of CIIE and Global Creativity Index

\begin{tabular}{|l|c|}
\hline & $\begin{array}{c}\text { P-value of Kolmogorov-Smirnov } \\
\text { criterion }\end{array}$ \\
\hline CIIE & 0.97 \\
\hline Global Creativity Index & 0.33 \\
\hline
\end{tabular}

Since the data is distributed normally (P-value of Kolmogorov-Smirnov criterion $>0.05$, see Table 10), Pearson correlation coefficient denoting correlation strength among variables is calculated (Table 11).

Table 11

Pearson Correlation Coefficient

\begin{tabular}{|l|c|}
\hline Pearson correlation coefficient & 0.7082 \\
\hline P-value of Kolmogorov-Smirnov criterion & 0.0000 \\
\hline N & 28 \\
\hline
\end{tabular}

Calculations confirm direct dependence between assumptions about CI emergence and development and CI impact on national economy; based on this dependence, hierarchical clustering is performed, insights and recommendations on how to increase CI impact on national economy are offered. Hierarchical clustering is provided in Figure 3. 


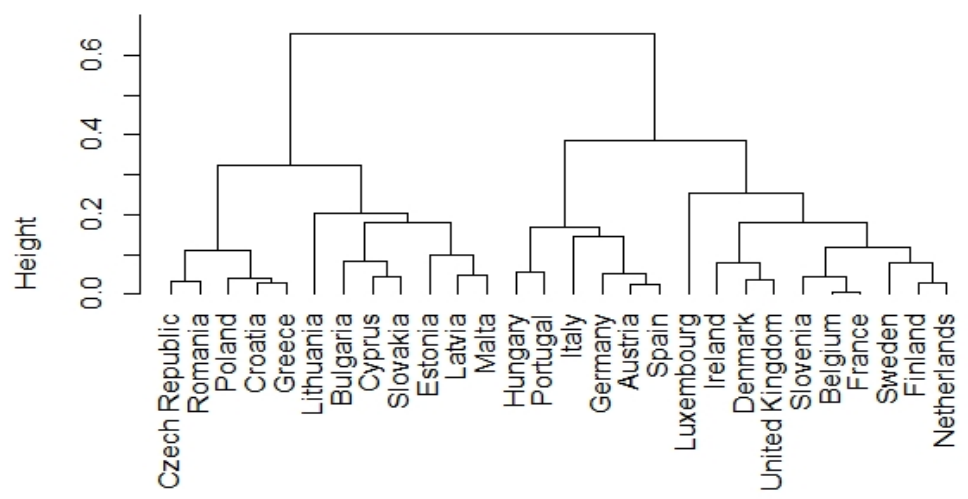

Figure 3. Hierarchical Clustering of EU Countries According to Conditions for the Development of CI and CI Impact on National Economy

According to the principles of this research, one cluster cannot contain more than $50 \%$ of countries, yet the number of clusters should be the least possible. Calculations allowed allocating all countries into the following three clusters:

$1^{\text {st }}$ cluster (12 countries): Czech Republic, Romania, Poland, Croatia, Greece, Lithuania, Bulgaria, Cyprus, Slovakia, Estonia, Latvia, Malta.

$2^{\text {nd }}$ cluster (6 countries): Hungary, Portugal, Italy, Germany, Austria, Spain.

$3^{\text {rd }}$ cluster (10 countries): Luxembourg, Ireland, Denmark, United Kingdom, Slovenia, Belgium, France, Sweden, Finland, Netherlands.
Most countries of the $1^{\text {st }}$ cluster are relatively new democracies, with past experiences that include loss of statehood, socialist, fascist cultural and political repressions, planned economy; these countries joined the European Union, and their respective democratic societies are still developing. $3^{\text {rd }}$ cluster countries are considered to have the best conducive environment for CI development and experience the highest CI impact on national economy.

To clearly identify country groups in terms of CI impact on economy and conditions for CI development, cluster assessments based on CIIE index of 2016, and the Global Creativity Index of 2015 are listed in Table 12.

Table 12

Average Scores of Cluster Countries by CIIE Index and Global Creativity Index

\begin{tabular}{|l|c|c|}
\hline \multicolumn{1}{|c|}{ Cluster } & $\begin{array}{c}\text { Average score of cluster countries by } \\
\text { GCI index (2015) }\end{array}$ & $\begin{array}{c}\text { Average score of cluster countries by } \\
\text { CIIE index (2016) }\end{array}$ \\
\hline $1^{\text {st }}$ cluster & 0.498 & 0.379 \\
\hline $2^{\text {nd }}$ cluster & 0.756 & 0.421 \\
\hline $3^{\text {rd }}$ cluster & 0.852 & 0.601 \\
\hline
\end{tabular}

Research data (see Table 12) confirms direct dependence between CI development conditions (estimated using GCI) and CI impact on national economy (estimated using CIIE); significant difference between the highest and the lowest scores by CIIE and GCI attributed to the country clusters exists.

Obviously, the $1^{\text {st }}$ cluster countries create the least favourable conditions for emergence and development of $\mathrm{CI}$; therefore, CI impact on national economy is the lowest.
Countries in the $2^{\text {nd }}$ cluster have average conditions for emergence and development of CI; thus, the impact of CI on national economy in these countries is rather high.

Finally, $3^{\text {rd }}$ cluster countries have favourable conditions for development of CI, hence the highest CI impact on national economy of cluster countries. Geographical distribution of clusters is mapped in Figure 4.

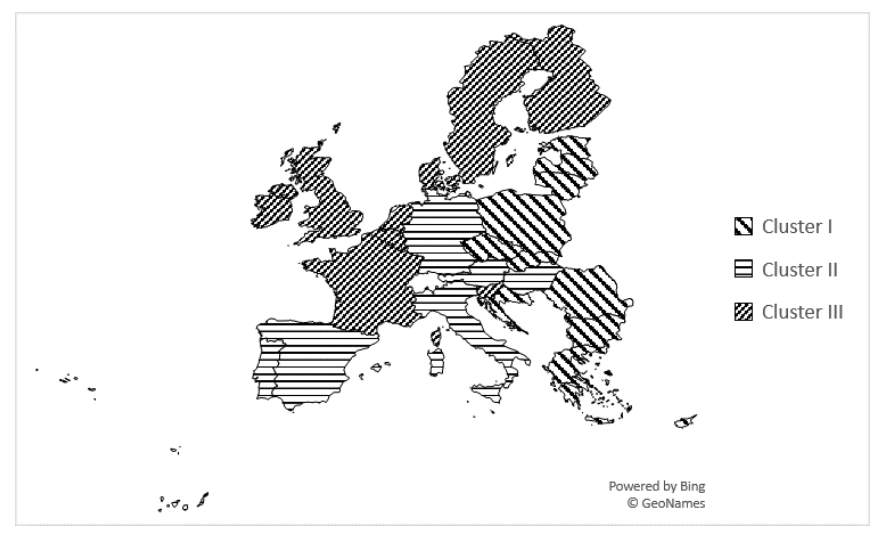

Figure 4. Geographic Distribution of Clusters 


\section{Discussion and Conclusions}

The research results show that the impact of $\mathrm{CI}$ is observed in economic, sociocultural, and environmental impact areas. Accordingly, CI promotion and development is not only beneficial economically (increase in new jobs, value added, and exports), which can be easily measured, but it is also helpful in solving social-cultural environment related issues (social development, quality of life, rural and urban development, and growth in social inclusion). It is important to note that CI contribute to air pollution less than other economy sectors, thus they have higher than average environmental impact.

CIIE index allows estimating CI impact on national economy and enables to draw comparisons among the EU countries in 2008-2016 based on CI impact on national economy. Theoretically, CIIE index may vary from 0 to 1 ; however, calculations revealed that its lowest value was estimated in Greece in 2011 (CIIE $=0.133)$, and the highest value was noted in the United Kingdom in 2016 $(\mathrm{CIIE}=0.684)$. Greece and Romania were estimated lowest CIIE index values during the studied period (Greece: 2008 -2015, Romania: 2016), while leading countries in terms of CI impact on national economy were Denmark (20082011), Luxembourg (2012-2014), and the United Kingdom (2015-2016).

Apart from statistical calculations, it is important to recognize that Europe is an extremely diverse continent and the EU countries have multiple connections and relationships between them, leading to spill over effects in neighbouring countries; they share historical circumstances of constituting one state or being at war with one another, and so on. Consequently, any mathematical analysis lacks identities of each country, which is an extremely important question when analysing such culture and history driven and formulated economy sector as creative industries. For the sake of this research, clusters are determined; however, this could be further analysed and explored, starting with one sector at a time. Study revealed direct dependence between factors of CI development and CI impact on national economy. With reference to the index describing the conditions of CI development (Global Creativity Index), three clusters of the EU countries were identified using CI impact on national economy (CIIE) index. Clustering confirms that historical, social, economic, and political development of a country determines conditions for CI emergence and development, and, consequently, influences CI impact on national economy. Thus, we conclude that in order to enhance the creative sector, various social and economic policy measures can be employed.

\section{Limitations and Practical Application of Research}

While the empirical research covers an outstanding amount of statistical data, there are limitations to the research, such as availability of the data (e.g., not all needed data was available, and it did not cover all the period evenly) and comparability of the data (research was built on data provided by EUROSTAT which might differ from analogous statistical data collected by other statistical offices).

However, since the research has covered and delved deeply into a significant number of theoretical studies, minted a general definition of CI and its constituents, and entails solid empirical research, it can be used by governmental and non-governmental organisations for policy making as well as by educational establishments in order to provide a simpler and clearer understanding of CI.

It is also fair to mention that no economic concept can be fully analysed without first examining its role in circular economy. Consequently, as circular economy is an extremely wide concept, covering various fields and reaching far beyond limits of traditional understanding of economy, it was considered a given in this research and was not analysed in detail. However, as the importance of circular economy increases, authors of the study admit it to have significant impact on CI and this could become a basis for further studies in the area.

It is important to note that the research was based on historical data analysis as specific circumstances are already known and can be evaluated and measured. Data analysis covered the period when the UK was still a part of the EU and pandemic was only foreseen as merely a futuristic idea. These and other changes must be considered, based on comparable and full data, and could become basis for further studies in the future.

Annex 1

Values of the CIIE Economic Impact Subindex 2008-2016

\begin{tabular}{|c|c|c|c|c|c|c|c|c|c|c|}
\hline & 2008 & 2009 & 2010 & 2011 & 2012 & 2013 & 2014 & 2015 & 2016 & Average \\
\hline Austria & 0.436 & 0.380 & 0.424 & 0.414 & 0.456 & 0.432 & 0.420 & 0.396 & 0.384 & 0.416 \\
\hline Belgium & 0.676 & 0.631 & 0.665 & 0.656 & 0.677 & 0.677 & 0.677 & 0.665 & 0.665 & 0.666 \\
\hline Bulgaria & 0.103 & 0.104 & 0.091 & 0.094 & 0.116 & 0.116 & 0.104 & 0.104 & 0.127 & 0.106 \\
\hline Cyprus & 0.295 & 0.307 & 0.364 & 0.400 & 0.399 & 0.411 & 0.423 & 0.447 & 0.446 & 0.388 \\
\hline Czechia & 0.354 & 0.321 & 0.336 & 0.255 & 0.277 & 0.265 & 0.254 & 0.230 & 0.242 & 0.282 \\
\hline Denmark & 0.402 & 0.345 & 0.344 & 0.287 & 0.329 & 0.305 & 0.294 & 0.294 & 0.282 & 0.320 \\
\hline Estonia & 0.553 & 0.514 & 0.477 & 0.488 & 0.505 & 0.516 & 0.505 & 0.505 & 0.540 & 0.511 \\
\hline Finland & 0.370 & 0.374 & 0.395 & 0.339 & 0.385 & 0.409 & 0.409 & 0.433 & 0.421 & 0.393 \\
\hline France & 0.434 & 0.446 & 0.479 & 0.493 & 0.514 & 0.502 & 0.502 & 0.514 & 0.514 & 0.489 \\
\hline Germany & 0.581 & 0.738 & 0.738 & 0.739 & 0.770 & 0.758 & 0.746 & 0.734 & 0.722 & 0.725 \\
\hline Greece & 0.510 & 0.498 & 0.549 & 0.515 & 0.536 & 0.524 & 0.524 & 0.500 & 0.488 & 0.516 \\
\hline Hungary & 0.286 & 0.275 & 0.215 & 0.172 & 0.193 & 0.193 & 0.181 & 0.181 & 0.158 & 0.206 \\
\hline Ireland & 0.295 & 0.295 & 0.271 & 0.271 & 0.259 & 0.295 & 0.295 & 0.272 & 0.332 & 0.287 \\
\hline Italy & 0.565 & 0.555 & 0.552 & 0.564 & 0.598 & 0.622 & 0.622 & 0.551 & 0.574 & 0.578 \\
\hline Latvia & 0.438 & 0.469 & 0.478 & 0.446 & 0.456 & 0.444 & 0.444 & 0.397 & 0.420 & 0.444 \\
\hline
\end{tabular}


Ugne Daubaraite-Radikiene, Grazina Startiene. Index-Based Measurement of Creative Industries' Impact on National Economy

\begin{tabular}{|l|c|c|c|c|c|c|c|c|c|c|}
\hline & $\mathbf{2 0 0 8}$ & $\mathbf{2 0 0 9}$ & $\mathbf{2 0 1 0}$ & $\mathbf{2 0 1 1}$ & $\mathbf{2 0 1 2}$ & $\mathbf{2 0 1 3}$ & $\mathbf{2 0 1 4}$ & $\mathbf{2 0 1 5}$ & $\mathbf{2 0 1 6}$ & Average \\
\hline Lithuania & 0.297 & 0.242 & 0.285 & 0.288 & 0.297 & 0.309 & 0.333 & 0.345 & 0.369 & 0.307 \\
\hline Luxembourg & 0.601 & 0.625 & 0.612 & 0.601 & 0.613 & 0.639 & 0.627 & 0.622 & 0.631 & 0.619 \\
\hline Malta & 0.559 & 0.593 & 0.570 & 0.559 & 0.559 & 0.559 & 0.559 & 0.559 & 0.548 & 0.563 \\
\hline Netherlands & 0.484 & 0.679 & 0.691 & 0.692 & 0.776 & 0.788 & 0.788 & 0.837 & 0.861 & 0.733 \\
\hline Norway & 0.692 & 0.671 & 0.658 & 0.594 & 0.582 & 0.582 & 0.594 & 0.594 & 0.593 & 0.618 \\
\hline Poland & 0.171 & 0.115 & 0.159 & 0.115 & 0.125 & 0.137 & 0.161 & 0.161 & 0.149 & 0.144 \\
\hline Portugal & 0.116 & 0.115 & 0.137 & 0.114 & 0.113 & 0.101 & 0.113 & 0.113 & 0.101 & 0.114 \\
\hline Romania & 0.183 & 0.171 & 0.184 & 0.220 & 0.252 & 0.287 & 0.276 & 0.381 & 0.299 & 0.250 \\
\hline Slovakia & 0.326 & 0.399 & 0.373 & 0.351 & 0.426 & 0.414 & 0.402 & 0.414 & 0.437 & 0.394 \\
\hline Slovenia & 0.497 & 0.485 & 0.544 & 0.546 & 0.588 & 0.588 & 0.600 & 0.565 & 0.565 & 0.553 \\
\hline Spain & 0.341 & 0.317 & 0.350 & 0.351 & 0.350 & 0.326 & 0.337 & 0.314 & 0.290 & 0.331 \\
\hline Sweden & 0.556 & 0.544 & 0.535 & 0.588 & 0.609 & 0.620 & 0.620 & 0.667 & 0.632 & 0.597 \\
\hline United Kingdom & 0.788 & 0.768 & 0.769 & 0.748 & 0.801 & 0.789 & 0.789 & 0.801 & 0.801 & 0.784 \\
\hline
\end{tabular}

Annex 2

Values of the CIIE Sociocultural Impact Subindex 2008-2016

\begin{tabular}{|c|c|c|c|c|c|c|c|c|c|c|}
\hline & 2008 & 2009 & 2010 & 2011 & 2012 & 2013 & 2014 & 2015 & 2016 & Average \\
\hline Austria & 0.478 & 0.522 & 0.546 & 0.579 & 0.562 & 0.525 & 0.592 & 0.609 & 0.597 & 0.557 \\
\hline Belgium & 0.611 & 0.616 & 0.611 & 0.595 & 0.605 & 0.576 & 0.571 & 0.605 & 0.612 & 0.600 \\
\hline Bulgaria & 0.278 & 0.295 & 0.311 & 0.284 & 0.246 & 0.235 & 0.246 & 0.289 & 0.301 & 0.276 \\
\hline Cyprus & 0.351 & 0.317 & 0.317 & 0.393 & 0.345 & 0.334 & 0.396 & 0.400 & 0.319 & 0.352 \\
\hline Croatia & 0.257 & 0.227 & 0.252 & 0.241 & 0.277 & 0.249 & 0.308 & 0.301 & 0.303 & 0.268 \\
\hline Czechia & 0.219 & 0.229 & 0.258 & 0.285 & 0.288 & 0.298 & 0.281 & 0.288 & 0.279 & 0.269 \\
\hline Denmark & 0.590 & 0.631 & 0.662 & 0.689 & 0.680 & 0.679 & 0.709 & 0.704 & 0.691 & 0.671 \\
\hline Estonia & 0.398 & 0.462 & 0.473 & 0.526 & 0.474 & 0.460 & 0.464 & 0.481 & 0.511 & 0.472 \\
\hline Finland & 0.664 & 0.699 & 0.703 & 0.722 & 0.733 & 0.725 & 0.767 & 0.761 & 0.727 & 0.722 \\
\hline France & 0.480 & 0.446 & 0.465 & 0.475 & 0.497 & 0.517 & 0.536 & 0.508 & 0.503 & 0.492 \\
\hline Germany & 0.539 & 0.571 & 0.569 & 0.586 & 0.579 & 0.569 & 0.608 & 0.602 & 0.575 & 0.577 \\
\hline Greece & 0.204 & 0.211 & 0.158 & 0.161 & 0.168 & 0.182 & 0.195 & 0.212 & 0.192 & 0.187 \\
\hline Hungary & 0.421 & 0.431 & 0.430 & 0.366 & 0.402 & 0.396 & 0.331 & 0.349 & 0.344 & 0.386 \\
\hline Ireland & 0.661 & 0.700 & 0.693 & 0.683 & 0.682 & 0.615 & 0.650 & 0.689 & 0.671 & 0.672 \\
\hline Italy & 0.406 & 0.415 & 0.375 & 0.390 & 0.420 & 0.403 & 0.417 & 0.424 & 0.388 & 0.404 \\
\hline Latvia & 0.380 & 0.464 & 0.448 & 0.455 & 0.445 & 0.414 & 0.408 & 0.460 & 0.469 & 0.438 \\
\hline Lithuania & 0.305 & 0.361 & 0.381 & 0.401 & 0.412 & 0.353 & 0.403 & 0.372 & 0.378 & 0.374 \\
\hline Luxembourg & 0.548 & 0.577 & 0.574 & 0.627 & 0.637 & 0.617 & 0.682 & 0.629 & 0.621 & 0.613 \\
\hline Malta & 0.477 & 0.432 & 0.460 & 0.462 & 0.410 & 0.413 & 0.425 & 0.334 & 0.380 & 0.421 \\
\hline Netherlands & 0.694 & 0.731 & 0.741 & 0.725 & 0.722 & 0.706 & 0.730 & 0.731 & 0.701 & 0.720 \\
\hline Poland & 0.245 & 0.272 & 0.360 & 0.370 & 0.356 & 0.356 & 0.376 & 0.386 & 0.308 & 0.337 \\
\hline Portugal & 0.355 & 0.330 & 0.336 & 0.295 & 0.320 & 0.338 & 0.318 & 0.319 & 0.327 & 0.327 \\
\hline Romania & 0.286 & 0.290 & 0.292 & 0.330 & 0.342 & 0.319 & 0.299 & 0.305 & 0.290 & 0.306 \\
\hline Slovakia & 0.269 & 0.224 & 0.293 & 0.299 & 0.284 & 0.262 & 0.251 & 0.285 & 0.291 & 0.273 \\
\hline Slovenia & 0.449 & 0.475 & 0.492 & 0.508 & 0.543 & 0.521 & 0.514 & 0.519 & 0.531 & 0.506 \\
\hline Spain & 0.526 & 0.542 & 0.534 & 0.520 & 0.555 & 0.549 & 0.583 & 0.555 & 0.560 & 0.547 \\
\hline Sweden & 0.672 & 0.728 & 0.731 & 0.727 & 0.720 & 0.721 & 0.751 & 0.744 & 0.731 & 0.725 \\
\hline United Kingdom & 0.606 & 0.626 & 0.629 & 0.660 & 0.660 & 0.635 & 0.658 & 0.630 & 0.624 & 0.636 \\
\hline
\end{tabular}

Annex 3

Values of the CIIE Environmental Impact Subindex 2008-2016

\begin{tabular}{|c|c|c|c|c|c|c|c|c|c|c|}
\hline & 2008 & 2009 & 2010 & 2011 & 2012 & 2013 & 2014 & 2015 & 2016 & Average \\
\hline Austria & 0.143 & 0.143 & 0.143 & 0.143 & 0.143 & 0.143 & 0.143 & 0.179 & 0.179 & 0.151 \\
\hline Belgium & 0.071 & 0.071 & 0.071 & 0.071 & 0.036 & 0.036 & 0.036 & 0.214 & 0.214 & 0.091 \\
\hline Bulgaria & 0.893 & 0.893 & 0.857 & 0.893 & 0.786 & 0.929 & 0.929 & 0.893 & 0.786 & 0.873 \\
\hline Cyprus & 0.714 & 0.750 & 0.679 & 0.679 & 0.643 & 0.679 & 0.679 & 0.500 & 0.536 & 0.651 \\
\hline Croatia & 0.357 & 0.500 & 0.429 & 0.464 & 0.464 & 0.500 & 0.500 & 0.286 & 0.321 & 0.425 \\
\hline Czechia & 0.679 & 0.714 & 0.607 & 0.643 & 0.607 & 0.679 & 0.679 & 0.643 & 0.250 & 0.611 \\
\hline Denmark & 0.857 & 0.857 & 0.821 & 0.786 & 0.750 & 0.786 & 0.786 & 0.857 & 0.857 & 0.817 \\
\hline Estonia & 0.286 & 0.286 & 0.536 & 0.821 & 0.571 & 0.250 & 0.250 & 0.321 & 0.357 & 0.409 \\
\hline Finland & 0.571 & 0.607 & 0.571 & 0.571 & 0.500 & 0.571 & 0.571 & 0.357 & 0.500 & 0.536 \\
\hline France & 0.393 & 0.393 & 0.321 & 0.357 & 0.321 & 0.357 & 0.357 & 0.250 & 0.286 & 0.337 \\
\hline Germany & 0.107 & 0.107 & 0.214 & 0.179 & 0.214 & 0.214 & 0.214 & 0.143 & 0.143 & 0.171 \\
\hline Greece & 0.036 & 0.036 & 0.036 & 0.036 & 0.071 & 0.107 & 0.107 & 0.357 & 0.500 & 0.143 \\
\hline
\end{tabular}


Inzinerine Ekonomika-Engineering Economics, 2022, 33(1), 13-26

\begin{tabular}{|c|c|c|c|c|c|c|c|c|c|c|}
\hline & 2008 & 2009 & 2010 & 2011 & 2012 & 2013 & 2014 & 2015 & 2016 & Average \\
\hline Hungary & 0.321 & 0.321 & 0.286 & 0.321 & 0.286 & 0.286 & 0.286 & 0.536 & 0.571 & 0.357 \\
\hline Ireland & 0.500 & 0.571 & 0.500 & 0.500 & 0.429 & 0.429 & 0.429 & 0.714 & 0.714 & 0.532 \\
\hline Italy & 0.857 & 0.857 & 0.857 & 0.857 & 0.821 & 0.893 & 0.893 & 0.786 & 0.821 & 0.849 \\
\hline Latvia & 0.536 & 0.643 & 0.643 & 0.714 & 0.679 & 0.607 & 0.607 & 0.821 & 0.786 & 0.671 \\
\hline Lithuania & 0.464 & 0.536 & 0.464 & 0.286 & 0.357 & 0.321 & 0.321 & 0.821 & 0.750 & 0.480 \\
\hline Luxembourg & 0.786 & 0.821 & 0.786 & 0.750 & 0.821 & 0.857 & 0.857 & 0.786 & 0.857 & 0.813 \\
\hline Malta & 0.179 & 0.214 & 0.107 & 0.107 & 0.107 & 0.071 & 0.071 & 0.071 & 0.036 & 0.107 \\
\hline Netherlands & 0.321 & 0.429 & 0.357 & 0.393 & 0.357 & 0.393 & 0.393 & 0.464 & 0.464 & 0.397 \\
\hline Poland & 0.214 & 0.250 & 0.179 & 0.250 & 0.250 & 0.250 & 0.250 & 0.429 & 0.429 & 0.278 \\
\hline Portugal & 0.750 & 0.786 & 0.714 & 0.714 & 0.714 & 0.750 & 0.750 & 0.750 & 0.750 & 0.742 \\
\hline Romania & 0.607 & 0.679 & 0.750 & 0.607 & 0.607 & 0.643 & 0.643 & 0.107 & 0.107 & 0.528 \\
\hline Slovakia & 0.929 & 0.929 & 0.893 & 0.929 & 0.821 & 0.821 & 0.821 & 0.679 & 0.679 & 0.833 \\
\hline Slovenia & 0.643 & 0.464 & 0.429 & 0.536 & 0.536 & 0.536 & 0.536 & 0.607 & 0.643 & 0.548 \\
\hline Spain & 0.821 & 0.571 & 0.821 & 0.750 & 0.714 & 0.714 & 0.714 & 0.393 & 0.393 & 0.655 \\
\hline Sweden & 0.250 & 0.179 & 0.250 & 0.214 & 0.179 & 0.179 & 0.179 & 0.036 & 0.071 & 0.171 \\
\hline United Kingdom & 0.429 & 0.357 & 0.393 & 0.429 & 0.393 & 0.464 & 0.464 & 0.571 & 0.607 & 0.456 \\
\hline
\end{tabular}

\section{References}

Bandarin, F., Hosagrahar, J., \& Albernaz, F. S. (2011). Why development needs culture. Journal of Cultural Heritage Management and Sustainable Development, 1(1), 15-25. https://doi.org/10.1108/20441261111129906

Barauskaite, D., \& Verikiene, J. (2011). Research report on the development of cultural and creative industries in Lithuanian regions. Vilnius: National association of creative and cultural industries. (in lithuanian)

Bilan, Y., Vasilyeva, T. Kryklii, O., \& Shilimbetova, G. (2019). The creative industry as a factor in the development of the economy: dissemination of European experience in the countries with economies in transition. Creativity studies, 12(1), 75-101. https://doi.org/10.3846/cs.2019.7453

Blair, H., Grey, S., \& Randle, K. (2001). Working in film. Employment in a project-based industry. Personnel Review, 30(2), 170-185. https://doi.org/10.1108/00483480110380334

Boschma, R. A., \& Fritsch, M. (2007). Creative class and regional growth in Europe. In P. Jacubowska, A. Kuklinski and P. Zuber (Eds.). The future of European regions (pp. 243-253). Warszaw: Ministry of Regional Development. http://citeseerx.ist.psu.edu/viewdoc/download?doi=10.1.1.520.9614\&rep=rep1\&type=pdf. Accessed 6 June 2018.

Champion, K. (2010). Hobson's choice? Constraints on accessing spaces of creative production in a transforming industrial conurbation. Creative Industries Journal, 3(1), 11-28. https://doi.org/10.1386/cij.3.1.11_1

Collins, P., Mahon, M. \& Murtagh, A. (2018). Creative industries and the creative economy of the West of Ireland: evidence of sustainable change?, Creative Industries Journal, 11(1), 70-86. https://doi.org/10.1080/17510694.2018.1434359

Comunian, R., Chapain, C., \& Clifton, N. (2010). Location, location, location: exploring the complex relationship between creative industries and place. Creative Industries Journal, 3(1), 5-10. https://doi.org/10.1386/cij.3.1.5_2

Cong, P. T. (2019). Creative industries, Investment trends and their impact on the Economy and Financial Sectors: A study from Vietnam. International Journal of Innovation, Creativity and Change, 7(5), 31-49. https://doi.org/10.53 333/IJICC2013/07504

Cunningham, S., \& Potts, J. (2014). Creative industries and the wider economy. In C. Jones, M. Lorenzen, and J. Sapsed (Eds.), The Oxford handbook of creative industries (pp. 387-404). Oxford: Oxford University Press, United Kingdom, https://doi.org/10.1093/oxfordhb/9780199603510.013.007

Daubaraite U., \& Startiene G. (2017). The Role of Creative Industries in Economic Development of Lithuania and Latvia. In: Bilgin M., Danis H., Demir E., Can U. (Eds.), Country experiences in economic development, management and entrepreneurship. Eurasian studies in business and economics, vol. 5, (pp. 91-103). Springer, Cham, https://doi.org/10.1007/978-3-319-46319-3_5

Daubaraite, U., \& Startiene, G. (2015). Creative industries impact on national economy in regard to sub-sectors. Procedia social and behavioral sciences, 213, 129-134. https://doi.org/10.1016/j.sbspro.2015.11.415.

De Beukelaer, C. (2014) Creative industries in "developing” countries: Questioning country classifications in the UNCTAD creative economy reports, Cultural Trends, 23(4), 232-251. https://doi.org/10.1080/09548963.2014.912043

De Propris, L. (2013). How are creative industries weathering the crisis? Cambridge Journal of Regions, Economy and Society, 6(1), 23-35. https://doi.org/10.1093/cjres/rss025

Ernst and Young, EY (2014). Creating growth. Measuring cultural and creative markets in the EU. http://www.creatingeurope.eu/en/wp-content/uploads/2014/11/study-full-en.pdf. Accessed 6 June 2017

European Commission, EC (2010). Green paper. Unlocking the potential of cultural and creative industries. https:/eurlex.europa.eu/legal-content/EN/TXT/PDF/?uri=CELEX:52010DC0183\&from=EN. Accessed 2 January 2017 
European Parliament and EU Council (2013). Regulation (EU) No 1295/2013 of the European Parliament and of the Council of 11 december 2013 establishing the Creative Europe Programme (2014 to 2020) and repealing Decisions No 1718/2006/EC, No 1855/2006/EC and No 1041/2009/EC. https://eur-lex.europa.eu/eli/reg/2013/1295/2018-01-01. Accessed 8 May 2018

Eurostat. (2008). Reference and Management of Nomenclatures, RAMON. Statistical classification of economic activities in the European community, Rev. 2. https://ec.europa.eu/eurostat/ramon/nomenclatures/index.cfm?TargetUrl= LST_NOM_DTL\&StrNom=NACE_REV2. Accessed 18 September 2017

Eurostat. (2017a). Average number of usual weekly hours of work in main job, by sex, professional status, full-time/parttime and economic activity (from 2008 onwards, NACE Rev. 2) - hours. http://appsso.eurostat.ec.europa. eu/nui/show.do?dataset=lfsa_ewhun2\&lang=en. Accessed 6 September 2017

Eurostat. (2017b). Gender pay gap in unadjusted form by NACE Rev. 2 activity - structure of earnings survey methodology. http://bit.ly/37XSNaU. Accessed 6 September 2017

Eurostat. (2017c). National accounts employment data by industry (up to NACE A*64). http://appsso.eurostat.ec.europa.eu/ nui/show.do?dataset=nama_10_a64_e\&lang=en. Accessed 6 September 2017

Eurostat. (2017d). Gross value added and income by $A * 10$ industry breakdowns. http://appsso.eurostat.ec.europa.eu/ nui/show.do?dataset=nama_10_a10\&lang=en. Accessed 15 September 2017

Eurostat. (2017e). Air emissions accounts by NACE Rev. 2 activity. https://appsso.eurostat.ec.europa.eu/nui/ show.do?dataset=env_ac_ainah_r2\&lang=en. Accessed 6 September 2017

Eurostat. (2017f). Business demography by legal form (from 2004 onwards, NACE Rev. 2). http://appsso.eurostat.ec. europa.eu/nui/show.do?dataset=bd_9ac_1_form_r2\&lang=en. Accessed 6 September 2017

Eurostat. (2017g). Educational attainment level and transition from education to work (based on EU-LFS). https://ec.europa.eu/eurostat/cache/metadata/en/edat1_esms.htm. Accessed 22 October 2017

Eurostat. (2017h). Employees by educational attainment level, sex, age and NACE Rev. 2 activity (\%). http://appsso.eurostat.ec.europa.eu/nui/show.do?dataset=edat_lfs_9910\&lang=en. Accessed 6 September 2017

Eurostat. (2017i). International Standard Classification of Education (ISCED). https://ec.europa.eu/eurostat/statisticsexplained/index.php/International_Standard_Classification_of_Education_(ISCED)\#Levels_of_education_in_ISCED _2011. Accessed 22 April 2017

Eurostat. (2017j). Mean consumption expenditure per household by COICOP consumption purpose (in PPS). http://appsso.eurostat.ec.europa.eu/nui/show.do?dataset=hbs_exp_t121\&lang=en. Accessed 17 September 2017

Eurostat. (2017k). Persons participating in cultural activities in the last 12 months by sex and age. http://appsso.eurostat.ec. europa.eu/nui/show.do?dataset=cult_pcs_caa\&lang=en. Accessed 6 September 2017

Eurostat. (20171). Glossary: Purchasing power standard (PPS). https://ec.europa.eu/eurostat/statistics-explained/ index.php/Glossary:Purchasing_power_standard_(PPS). Accessed 13 May 2017

Eurostat. (2017m). Quality of life indicators - measuring quality of life. https://ec.europa.eu/eurostat/statisticsexplained/index.php/Quality_of_life_indicators___measuring_quality_of_life. Accessed 10 August 2017

Eurostat. (2017n). Archive: Regional competitiveness statistics. https://ec.europa.eu/eurostat/statistics-explained/index.php? title=Archive:Regional_competitiveness_statistics. Accessed 21 August 2017

Fanea-Ivanovici, M. \& Pana, M. (2020). From Culture to Smart Culture. How Digital Transformations Enhance Citizens' Well-Being Through Better Cultural Accessibility and Inclusion. IEEE Access, 8, (37988-38000). https://doi.org/10.1109/ACCESS.2020.2975542

Flew, T. (2002). Beyond ad hocery: defining creative industries. In M. Volkerling (Ed.), Proceedings cultural sites, cultural theory, cultural policy. Second international conference of cultural policy research (pp. 181-191). Wellington, New Zealand, 23-26 January,

Florida, R. (2008). Who's your city? How the creative economy is making where to live the most important decision of your life. New York: Basic Books.

Florida, R., \& Tinagli, I. (2004). Europe in the creative age. http://creativeclass.com/rfcgdb/articles/Europe_in_the_ Creative_Age_2004.pdf. Accessed 2 January 2017

Florida, R., Mellander, Ch., \& King, K. (2015). The Global Creativity Index 2015. https://ec.europa.eu/futurium/en/content/ global-creativity-index-2015-most-creative-countries. Accessed 24 September 2018

Florida, R. (2002). The rise of the creative class: and how it's transforming work, leisure, community and everyday life. New York: Basic Books

Fox, M. S. (2013). A foundation ontology for global city indicators. Global Cities Institute Working Paper No. 03. https://www.researchgate.net/publication/262675058_A_Foundation_Ontology_for_Global_City_Indicators. Accessed 2 January 2017 
Garnham, N. (2005). From cultural to creative industries. An analysis of the implications of the "creative industries" approach to arts and media policy making in the United Kingdom. International Journal of Cultural Policy, 11(1), 15 -29. https://doi.org/10.1080/10286630500067606

Goede M., \& Louisa, G. (2012). A case study of the creative zone Scharloo and Pietermaai in Curaçao. International Journal of Social Economics, 39(11), 844-858. https://doi.org/10.1108/03068291211263899

Hotho, S., \& Champion, K. (2011). Small businesses in the new creative industries: innovation as a people management challenge. Management Decision, 49(1), 29-54. https://doi.org/10.1108/00251741111094428

Hui, D., Chung-hung, NG, Mok, P., Fong, N., Chin, W., \& Yuen, Ch. (2006). A study on creativity index. https://www.hab.gov.hk/ file_manager/en/documents/policy_responsibilities/arts_culture_recreation_and_sport/HKCI-InteriReport-printed.pdf. Accessed 11 June 2017

Innocenti, N. \& Lazzeretti, L. (2019) Do the creative industries support growth and innovation in the wider economy? Industry relatedness and employment growth in Italy, Industry and Innovation, 26(10), 1152-1173. https://doi.org/10.1 080/13662716.2018.1561360

Jancoras, Z., Surviliene, R., Strazdas, R., Cerneviciute, J., Morkevicius, V., Makselis, R., Stanikunas, R., Kregzdaite, R., Daubaraite, U., et al. (2014). Competitiveness of Lithuanian creative and cultural industries in the domestic and foreign market. Vilnius: National association of creative and cultural industries. (in lithuanian)

KEA. European Affairs. (2006). The economy of culture in Europe. https:/ec.europa.eu/assets/eac/culture/ library/studies/cultural-economy_en.pdf. Accessed 2 January 2017

Knoema (2017). Exports of goods by economic activity (NACE Rev. 2) and partner - \% of GVA. http://bit.ly/38RS2kV. Accessed 17 September 2017

Levickaite, R., \& Reimeris, R. (2011). A pentagon of creative economy. Santalka: Filosofija, Komunikacija, 19(1), 83-91. https://doi.org/10.3846/coactivity.2011.09. (in lithuanian)

Matheson, B. (2006). A culture of creativity: design education and the creative industries. Journal of Management Development, 25(1), 55-64. https://doi.org/10.1108/02621710610637963.

Oakley, K. (2004). Not so cool Britannia: the role of the creative industries in economic development. International Journal of Cultural Studies, 7(1), 67-77. https://doi.org/10.1177/1367877904040606.

OECD. (2013). OECD guidelines on measuring subjective well-being. https://www.oecd.org/statistics/oecd-guidelines-onmeasuring-subjective-well-being-9789264191655-en.htm. Accessed 10 August 2018.

OECD. (2018). OECD regional well-being. Using data to build better communities. https://www.oecdregional wellbeing.org/assets/downloads/Regional-Well-Being-User-Guide.pdf. Accessed 10 December 2018

Oxford Economics, OE (2014). The economic impact of the creative industries in the Americas. https://www.oxfordeconomics.com/my-oxford/projects/266568 Accessed 25 December 2017

Pitts, F. H. (2015). A hidden history: defining and specifying the role of the creative industries. Creative Industries Journal, 8(1), 73-84. https://doi.org/10.1080/17510694.2015.1048068.

Potts, J., \& Cunningham, S. (2008). Four models of the creative industries. International Journal of Cultural Policy, 14(3), 233-247. https://doi.org/10.1080/10286630802281780.

Power, D., \& Nielsen, T. (2010). Priority sector report: creative and cultural industries. Europe Innova, European Cluster Observatory. http://volanteresearch.com/wp-content/uploads/2013/10/Priority-Sector-Report-Creative-and-CulturalIndustries-Main-report.pdf. Accessed 16 January 2017

Pratt, A. C. (2008) Creative cities: the cultural industries and the creative class. Geografiska annaler: Series B - Human geography, 90(2), 107-117. https://doi.org/10.1111/j.1468-0467.2008.00281.x.

Reporters Without Borders. World press freedom index. https://rsf.org/en/ranking/2016. Accessed 12 September 2017

Sigurdardottir, M. S., \& Young, T. (2011). Towards creative Iceland: building local, going global. Quantitative and qualitative mapping of the cultural and creative sectors in Iceland. http://www.icelanddesign.is/media/ PDF/towardscreativeicelandreport1.pdf. Accessed 29 July 2017

Smallbone, D., Bertotti, M., \& Ekanem, I. (2005). Diversification in ethnic minority business. The case of Asians in London's creative industries. Journal of Small Business and Enterprise Development, 12(1), 41-56. https://doi.org/10.1108/14626000510579635

Social Progress Imperative. (2016). 2016 Social progress index. Interactive resource. https://www.socialprogress.org/ resources?filter $=2016$. Accessed 6 September 2017

Thomassen, A. (2007). Design of the netgeneration. Streaming the flow of design and science in the educational practice of the creative industry. Kybernetes, 36(9/10), 1529-1542. https://doi.org/10.1108/03684920710827463

Tomczak, P., \& Stachowiak, K. (2015) Location patterns and location factors in cultural and creative industries. Quaestiones Geographicae, 34(2), 7-27. https://doi.org/10.1515/ quageo-2015-0011. 
UNESCO. (2006). Understanding creative industries. Cultural statistics for public - policy making. https://www.americansforthearts.org/sites/default/files/pdf/2015/international/UNESCO_Understanding_Creative_Industries.pdf. Accessed 2 January 2017

United Nations Conference on Trade and Development, UNCTAD. (2008). Creative economy report 2008. The challenge of assessing the creative economy: towards informed policy-making. Geneva: United Nations. https://unctad.org/ en/Docs/ditc20082cer_en.pdf. Accessed 8 September 2017

United Nations Development Programme, UNDP. (2013). Creative economy report 2013. Special edition: widening local development pathways. Paris: UNDP. http://www.unesco.org/culture/pdf/creative-economy-report-2013.pdf. Accessed 4 February 2017

United Nations, UN. (2007). Indicators of sustainable development: guidelines and methodologies. Third edition. New York: United Nations. https://www.un.org/esa/sustdev/natlinfo/indicators/guidelines.pdf. Accessed 4 February 2017

van der Pol, H. (2007). Key role of cultural and creative industries in the economy. https://www.oecd.org/ site/worldforum06/38703999.pdf Accessed 29 July 2017

White D. S., Gunasekaran A., \& Roy M. H. (2014). Performance measures and metrics for the creative economy. Benchmarking: An International Journal, 21(1), 46-61. https://doi.org/10.1108/BIJ-03-2012-0017.

White, P. (2010). Creative industries in a rural region: Creative west: the creative sector in the western region of Ireland. Creative Industries Journal, 3(1), 79-88. https://doi.org/10.1386/cij.3.1.79_1.

Yum, S. (2020). The relationship between creative industries and the urban economy in the USA, Creative Industries Journal, 13(2), 95-116. https://doi.org/10.1080/17510694.2019.1668741.

\section{Authors' Biographies}

Grazina Startiene is Professor in Economics at the School of Economics and Business, Kaunas University of Technology, Lithuania. Her research interests include international economics and trade, currency and international settlement, industry competitiveness. ORCID iD https://orcid.org/0000-0002-9671-8900

Ugne Daubaraite - Radikiene is a doctor of science in the field of Social Sciences (Economics), a researcher of the research group "Sustainable Economy" of Kaunas University of Technology, School of Economics and Business. She received undergraduate degree in Business Management, graduate degree in Economics (Marketing) and a Ph.D. in Economics at Kaunas University of Technology. Ugne has experience in various research and study projects. Her main areas of scientific interest are creative and cultural industries, creative economy.

The article has been reviewed. Received in October 2020; accepted in February 2022.

This article is an Open Access article distributed under the terms and conditions of the Creative Commons Attribution 4.0 (CC BY 4.0) License http://creativecommons.org/licenses/by/4.0 